Article

\title{
Evaluation of the Immunomodulatory Effects of Fucoidan Derived from Cladosiphon Okamuranus Tokida in Mice
}

\author{
Makoto Tomori $^{1,2, *(D)}$, Takeaki Nagamine ${ }^{3}$, Tomofumi Miyamoto ${ }^{2}$ and Masahiko Iha ${ }^{1}$ \\ 1 South Product Co., Ltd., Uruma 904-2234, Japan; miha.south@nifty.com \\ 2 Graduate School of Pharmaceutical Sciences, Kyushu University, Fukuoka 812-8582, Japan; \\ miyamoto@phar.kyushu-u.ac.jp \\ 3 Department of Health and Nutrition, Takasaki University of Health Science, Takasaki 370-0036, Japan; \\ nagamine-t@kendai-clinic.jp \\ * Correspondence: m-tomori@south-p.co.jp; Tel.: +81-98-982-1272; Fax: +81-98-921-3038
}

Received: 14 August 2019; Accepted: 23 September 2019; Published: 24 September 2019

\begin{abstract}
Okinawa mozuku (Cladosiphon okamuranus Tokida) is an edible seaweed classified as brown algae and is a native species of the Ryukyu Islands in Japan. In recent years, the genomic decoding of Okinawa mozuku has been completed. Previous studies on the anti-inflammatory, antiviral, and antitumor properties of Okinawa mozuku have suggested that it affects the regulation of cellular and humoral immunity. The aim of the present study was to examine the immunoregulatory effect of fucoidan derived from Okinawa mozuku in mice. A product containing fucoidan (purity, $88.3 \%$; molecular weight, $49.8 \mathrm{kDa}$ ) was developed from Okinawa mozuku and tested for its immunoregulatory effects in mice. The experimental animals were 8-week-old female BALB/c mice to which fucoidan $(0,102.5,205.0,410.0$, and $1025.0 \mathrm{mg} / \mathrm{kg}$ ) was administered orally continuously for six weeks. Immune cell proliferation, cytokine production, macrophage phagocytosis, and serum antibody concentration were measured. We found that immune cell proliferation, interleukin (IL)-2, macrophage phagocytes, and serum antibodies (IgM, -G, -A) increased significantly, but IL-4, -5, and IgE decreased significantly. These results indicated that fucoidan modulated cellular and humoral immunity.
\end{abstract}

Keywords: Cladosiphon okamuranus; fucoidan; immune cell proliferation; immunomodulatory

\section{Introduction}

Fucoidan is a generic term for various water-soluble sulfated polysaccharides present in brown algae. These compounds exhibit many different biological properties, including anti-inflammatory [1,2], anticoagulant [1], anti-HIV [3], and antitumor [4-7] effects. The biological properties of fucoidan vary depending on the species of algae, molecular weight, composition, and structure. Fucoidan derived from Gagome kombu (Kjellmaniella crassifolia) has been confirmed to be safe in healthy volunteer subjects [8] and has been reported to prevent immune function deterioration. Fucoidan derived from Mekabu (Undaria pinnatifida) increased helper T1 cells in BALB/c mice [9]. Okinawa mozuku (Cladosiphon okamuranus), the raw material of fucoidan used in this study, is an edible seaweed of the Ryukyu archipelago, Japan. The cultivation of Okinawa mozuku in Okinawa Prefecture was established by the Okinawa Prefectural Fisheries Research and Extension Center in the 1970s, and the prefecture is currently capable of providing large-scale production and a stable supply of this seaweed that accounts for $>90 \%$ of domestic distribution in Japan. Recently, Nishitsuji et al. [10] decoded the draft genome of the Okinawa mozuku S-strain. This fucoidan has a linear backbone of 1-3-linked $\alpha$-fucopyranose with $50 \%$ sulfate substitution at the 4-positions, and some of the fucose residues are O-acetylated [11]. 
This particular fucoidan is characterized by a simpler structure than that of fucoidan derived from other brown algae, Gagome kombu and Mekabu, and exhibits many biological properties, including inhibition of the adhesion of Helicobacter pylori [12,13], improvement of functional dyspepsia [14,15], anti-fatigue activity $[6,16]$, and improvement in bowel movement $[17,18]$. A previous study on immunity reported anti-human T-cell leukemia virus type-I (HTLV-1) $[19,20]$ and antitumor [4-7] effects. However, the mechanism underlying the immunomodulatory effects of fucoidan derived from Okinawa mozuku has not been reported. In this study, we aimed to comprehensively investigate the immunomodulatory effect of fucoidan derived from Okinawa mozuku in mice.

\section{Results}

\subsection{Proliferative Activity of Splenic Immune Cells}

In an immune cell response, fucoidan at low (FL), middle (FM), middle high (FMH), and high (FH) doses significantly increased the proliferation activity of splenocytes stimulated by concanavalin A (Con A) and liposaccharide (LPS) (Table 1).

Table 1. Effect of fucoidan on immune cell proliferation.

\begin{tabular}{lccc}
\hline & & \multicolumn{2}{c}{ Stimulation Index (S.I.) } \\
\cline { 3 - 4 } Group & Dose $(\mathbf{m g} / \mathbf{k g})$ & Con A $(5.0 \mu \mathbf{g} / \mathbf{m L})$ & LPS $(\mathbf{1 0 . 0} \mu \mathbf{g} / \mathbf{m L})$ \\
\hline NC & - & $2.59 \pm 0.26^{\mathrm{a}}$ & $2.10 \pm 0.14^{\mathrm{a}}$ \\
FL & 102.5 & $2.94 \pm 0.29^{\mathrm{b}}$ & $2.42 \pm 0.15^{\mathrm{b}}$ \\
FM & 205.0 & $3.16 \pm 0.21^{\mathrm{b}, \mathrm{c}}$ & $2.45 \pm 0.19^{\mathrm{b}}$ \\
FMH & 410.0 & $3.40 \pm 0.28^{\mathrm{c}, \mathrm{d}}$ & $2.74 \pm 0.28^{\mathrm{c}}$ \\
FH & 1025.0 & $3.54 \pm 0.39^{\mathrm{d}}$ & $2.82 \pm 0.23^{\mathrm{c}}$ \\
\hline
\end{tabular}

All data are presented as mean $\pm \mathrm{SD}(n=10$ mice/group). All experiments were performed once per test condition. NC, negative control, FL, low dose fucoidan; FM, middle dose fucoidan; FMH, middle high dose fucoidan; FH, high dose fucoidan; Con A, concanavalin A; LPS, liposaccharide. Different letters indicate significant differences $(p<0.05)$.

\subsection{Effect of Fucoidan on Phagocytes Activity}

In respect to phagocytes, fucoidan treatment groups at FMH and FH doses displayed significantly increased phagocytosis activity in a dose-dependent manner at an Eschericia coli to macrophage ratio of 25:1. Moreover, phagocytes of fucoidan groups at FM, FMH, and FH doses were significantly increased in a dose-dependent manner at an E. coli to macrophage ratio of 50:1 (Figure 1). 


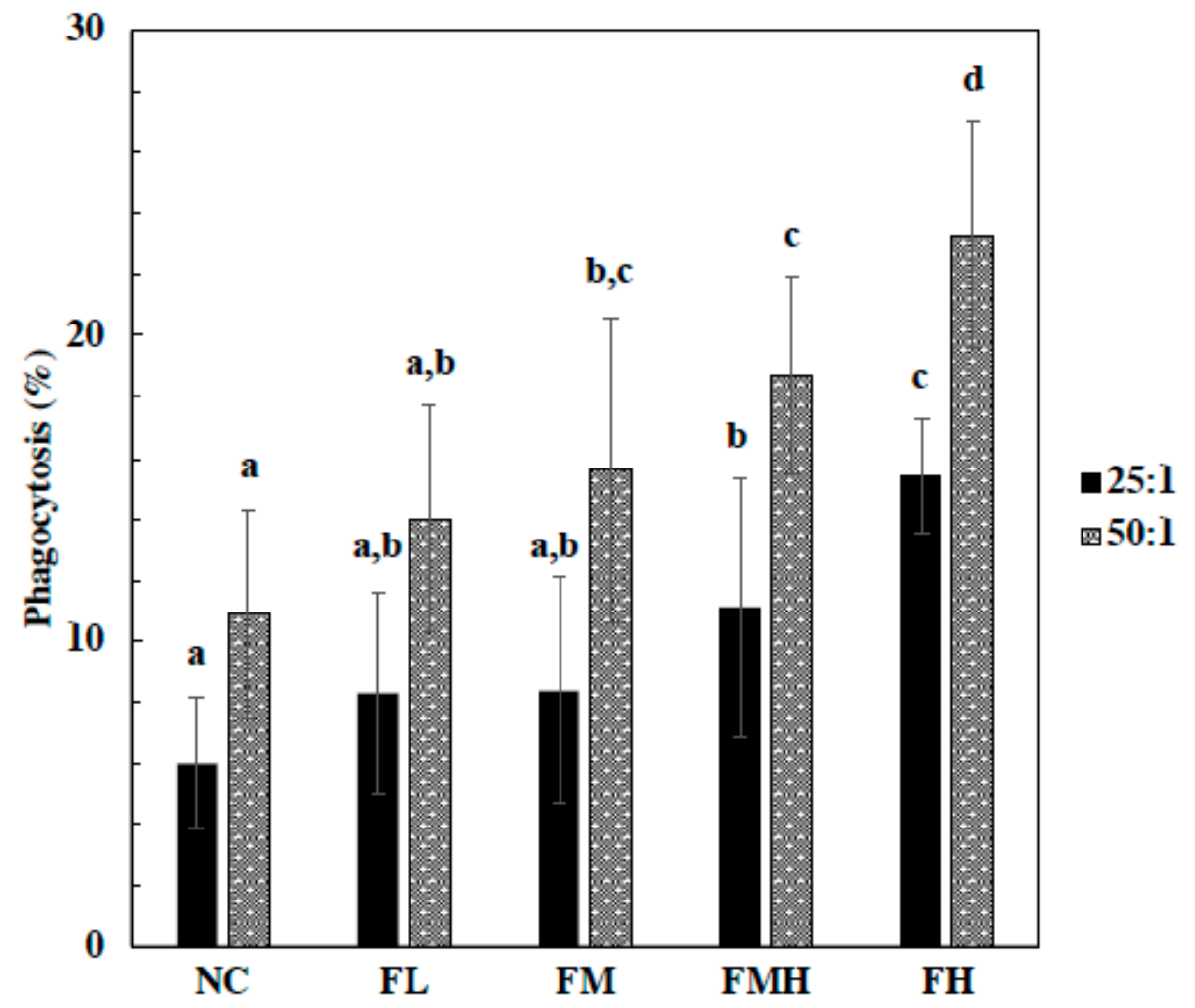

Figure 1. Effect of fucoidan on macrophage phagocytosis activity. The mice were administrated with fucoidan (FL, FM, FMH, FH) for 6 weeks. Peritoneal macrophage were isolated from mice and phagocytosis of fluorescence-labeled E. coli by macrophage was analyzed by flow cytometry. The macrophage to E. coli ratios were 25:1 and 50:1. All data were presented as mean \pm SD ( $n=10$ mice/group). All experiments were performed in once per test condition. Different alphabets were significantly $(p<0.05)$.

\subsection{Effect of Fucoidan on Cytokines Production}

In a cytokine production study, the splenocytes were isolated and stimulated by Con A and LPS. The levels of interleukin (IL)-2, IL-4, IL-5, and interferon (IFN)- $\gamma$ were analyzed (Table 2). The levels of IL-2 in the fucoidan groups were significantly increased by Con A and LPS stimulation, but the levels of IL- 4 and IL- 5 were significantly decreased. The levels of IFN- $\gamma$ in the fucoidan groups were significantly increased by LPS stimulation.

Table 2. Effect of fucoidan on cytokine production.

\begin{tabular}{cccc}
\hline Group & Dose $(\mathbf{m g} / \mathbf{k g})$ & Con A $(5.0 \mu \mathrm{g} / \mathbf{~ m L})$ & LPS $(\mathbf{1 0 . 0} \mu \mathrm{g} / \mathbf{m L})$ \\
\hline & & \multicolumn{2}{c}{ IL-2 $(\mathrm{pg} / \mathrm{mL})$} \\
NC & - & $2625.1 \pm 526.1^{\mathrm{a}}$ & $34.1 \pm 5.6^{\mathrm{a}}$ \\
FL & 102.5 & $2944.2 \pm 874.0^{\mathrm{a}, \mathrm{b}}$ & $38.9 \pm 6.8^{\mathrm{a}, \mathrm{b}}$ \\
FM & 205.0 & $3184.5 \pm 519.1^{\mathrm{a}, \mathrm{b}}$ & $39.3 \pm 3.5^{\mathrm{a}, \mathrm{b}}$ \\
FMH & 410.0 & $3223.4 \pm 539.6^{\mathrm{b}}$ & $39.9 \pm 5.6^{\mathrm{a}, \mathrm{b}}$ \\
FH & 1025.0 & $3249.2 \pm 452.4^{\mathrm{b}}$ & $41.9 \pm 10.1^{\mathrm{b}}$ \\
& & \multicolumn{2}{c}{ IL-4 $\left.^{\mathrm{a}} \mathrm{pg} / \mathrm{mL}\right)$} \\
NC & - & $51.9 \pm 11.2^{\mathrm{a}}$ & $14.3 \pm 2.8^{\mathrm{a}}$ \\
FL & 102.5 & $43.9 \pm 13.2^{\mathrm{a}}$ & $10.6 \pm 0.9^{\mathrm{b}}$ \\
FM & 205.0 & $41.4 \pm 15.0^{\mathrm{a}, \mathrm{b}}$ & $10.7 \pm 1.7^{\mathrm{b}}$ \\
FMH & 410.0 & $42.1 \pm 14.7^{\mathrm{a}, \mathrm{b}}$ & $10.2 \pm 1.2^{\mathrm{b}}$ \\
FH & 1025.0 & $31.2 \pm 8.8^{\mathrm{b}}$ & $9.7 \pm 0.8^{\mathrm{b}}$ \\
\hline
\end{tabular}


Table 2. Cont.

\begin{tabular}{cccc}
\hline Group & Dose $(\mathbf{m g} / \mathbf{k g})$ & Con A $(5.0 \mu \mathrm{g} / \mathbf{m L})$ & LPS $(\mathbf{1 0 . 0} \boldsymbol{\mu g} / \mathbf{m L})$ \\
\hline & & \multicolumn{2}{c}{ IL-5 $(\mathrm{pg} / \mathrm{mL})$} \\
NC & - & $121.9 \pm 41.3^{\mathrm{a}}$ & $10.0 \pm 1.8^{\mathrm{a}}$ \\
FL & 102.5 & $78.9 \pm 14.5^{\mathrm{b}}$ & $7.6 \pm 1.0^{\mathrm{b}}$ \\
FM & 205.0 & $71.6 \pm 17.6^{\mathrm{b}}$ & $7.4 \pm 1.0^{\mathrm{b}}$ \\
FMH & 410.0 & $68.4 \pm 15.7^{\mathrm{b}}$ & $7.1 \pm 0.7^{\mathrm{b}}$ \\
FH & 1025.0 & $65.8 \pm 19.2^{\mathrm{b}}$ & $7.0 \pm 0.8^{\mathrm{b}}$ \\
& & \multicolumn{2}{c}{ IFN- $(\mathrm{ng} / \mathrm{mL})$} \\
NC & - & $19.3 \pm 4.8^{\mathrm{a}}$ & $4.0 \pm 0.9^{\mathrm{a}}$ \\
FL & 102.5 & $20.4 \pm 5.3^{\mathrm{a}}$ & $5.1 \pm 1.3^{\mathrm{a}, \mathrm{b}}$ \\
FM & 205.0 & $24.3 \pm 6.8^{\mathrm{a}}$ & $5.9 \pm 2.4^{\mathrm{b}}$ \\
FMH & 410.0 & $24.4 \pm 7.7^{\mathrm{a}}$ & $6.6 \pm 1.9^{\mathrm{b}}$ \\
FH & 1025.0 & $24.5 \pm 5.2^{\mathrm{a}}$ & $8.8 \pm 2.8^{\mathrm{c}}$ \\
\hline
\end{tabular}

All data are presented as mean $\pm \mathrm{SD}(n=10$ mice/group). All experiments were performed once per test condition. Different letters indicate significant differences $(p<0.05)$.

\subsection{Effect of Fucoidan on Serum Antibody Production}

Serum immunoglobulin (Ig)G, IgM, IgA, and IgE were determined after administration of fucoidan (FL, FM, FMH, and FL) for six weeks (Figure 2). The serum antibodies in the fucoidan groups at the FMH and FH doses significantly increased in a dose-dependent manner for $\operatorname{IgG}$ (a) and $\operatorname{IgA}$ (Figure 2c). The serum IgM (Figure $2 b$ ) levels of the fucoidan groups significantly increased at all doses in a dose-dependent manner, but the serum IgE (Figure 2d) level significantly decreased.

(a)

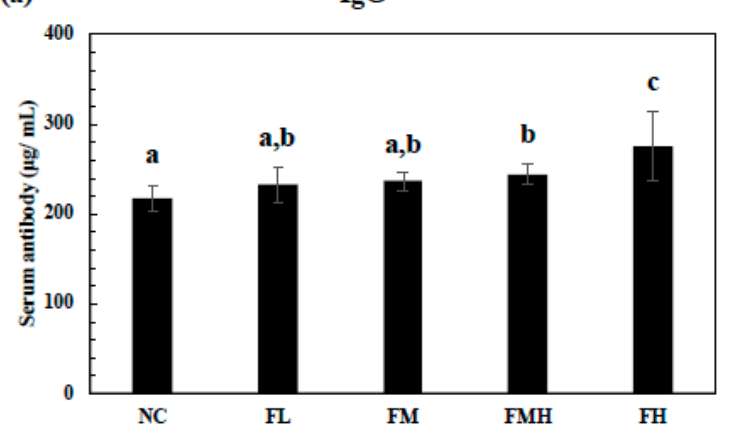

(c)

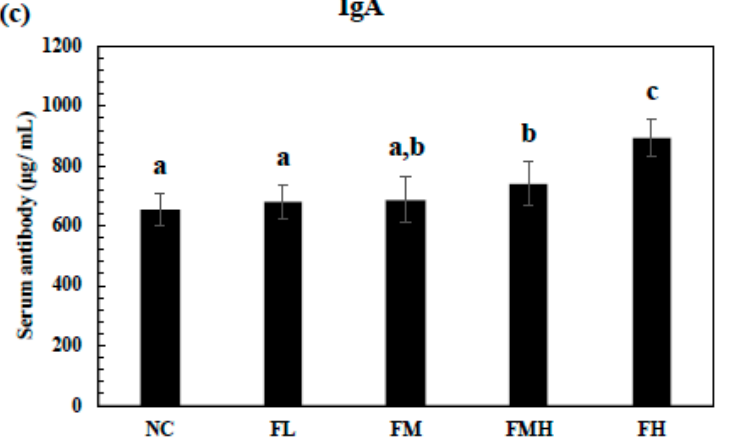

(b)

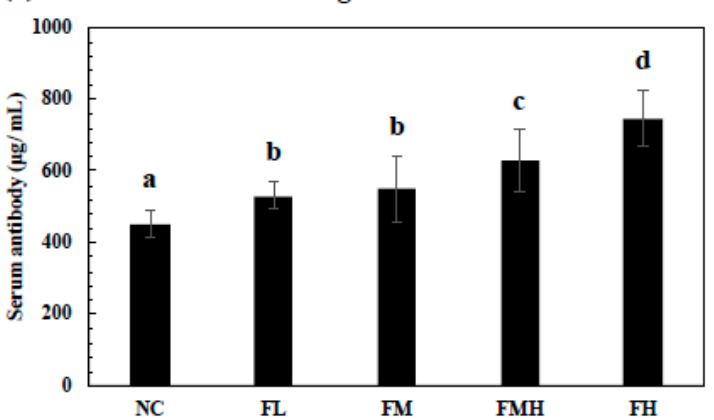

(d)

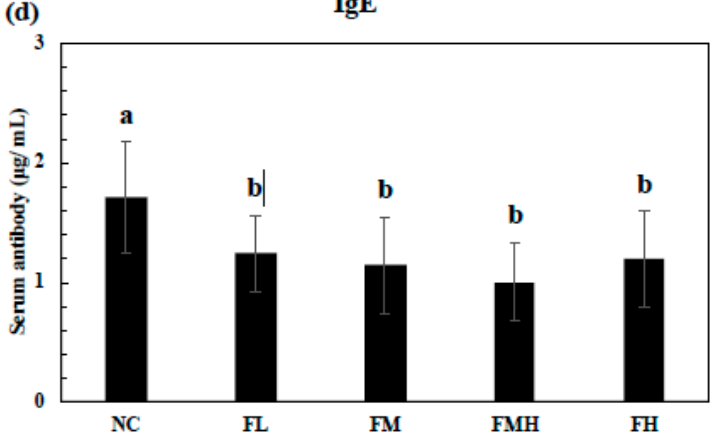

Figure 2. Effect of fucoidan on serum $\operatorname{IgG}(\mathbf{a}), \operatorname{IgM}(\mathbf{b}), \operatorname{IgA}(\mathbf{c})$, and $\operatorname{IgE}(\mathbf{d})$ production. The mice were administrated with fucoidan (FL, FM, FMH, FH) for 6 weeks. The serum was analyzed using ELISA assays. All data were presented as mean $\pm \mathrm{SD}(n=10 \mathrm{mice} / \mathrm{group})$. All the experiments were performed in once per test condition. Different alphabets were significantly different $(p<0.05)$. 


\section{Discussion}

The bioactivity of fucoidan is affected by its chemical structure and molecular weight. In addition, the chemical structure and molecular weight affect absorption and physiological activity in the body $[21,22]$. Previously, it has been reported that fucoidan is involved in immune activities, such as those of macrophages, NK cells, and cytokines [23,24]. Fucoidan derived from Okinawa mozuku has been confirmed to be absorbed by rodents and humans [25-27]. In this study, fucoidan was shown to be active in spleen immune cells, and macrophages in mice. For cytokines, IL-2 and IFN- $\gamma$ were increased, whereas IL-4 and IL-5 were reduced. Serum antibodies IgM, IgG, and IgA increased, but IgE decreased. Spleen cells and macrophage activity are affected by cytokines. The immune cells in the spleen are $\mathrm{T}$ and B cells. In this study, splenic immune cells were increased in the fucoidan administration groups. Con A promotes the differentiation of T cells, and LPS is a mitogen that promotes the differentiation of B cells. Fucoidan has been shown to activate the growth of $\mathrm{T}$ and $\mathrm{B}$ cells present in the spleen. Shimizu et al. [28] found that different molecular weights of fucoidan had different effects on the growth of $\mathrm{T}$ cells and NK cells derived from the spleen; they found that there was a greater effect on high molecular weight $\left(2 \times 10^{5}\right.$ to $\left.3 \times 10^{5}\right)$ fucoidan than on low molecular weight $\left(1 \times 10^{3}\right.$ to $9 \times 10^{3}$ ) fucoidan. The fucoidan used in this study was also high molecular weight and gave similar results. Jang et al. [29] reported that they observed a proliferative effect on mouse spleen cells by use of high molecular weight fucoidan (130 kDa). In our study, production of IL-2 and IFN- $\gamma$ were increased in the fucoidan administration groups. These results suggest that macrophage phagocytes' activity was stimulated. The activity of macrophages also has another mechanism. Doi et al. [30] showed that macrophages bind to various negatively charged molecules and reported that they were involved in biological defense mechanisms and processing mechanisms. The serum antibodies IgM, $\mathrm{IgG}$, and IgA were significantly increased, whereas IgE was significantly reduced. B cells are involved in antibody production, and IL-4, IL-21, TGF- $\beta$, and IFN- $\gamma$ are affected by their activity. In the case of fucoidan derived from Mekabu (Undaria pinnatifida) used by Takai et al. [31], a fucoidan with a molecular weight of $\geq 2 \mathrm{kDa}$ promoted $\operatorname{IgM}, \operatorname{IgG}$, and $\operatorname{IgA}$, with $\operatorname{IgE}$ reported to be below the detection limit. These test results suggested that a class switch of B cells caused by IFN- $\gamma$ was involved in the production promotion of IgM, IgG, and IgA. On the other hand, IL-4 and IL-5, which are involved in humoral immunity, were reduced in the fucoidan administration group. These results reveal that fucoidan has the ability to adjust the balance between cellular and humoral immunity.

\section{Materials and Methods}

\subsection{Fucoidan}

In this study, we used a fucoidan product called Mei Hai Yun ${ }^{\circledR}$, which was provided by Kanwa Healthcare Ltd. (New Taipei, Taiwan). Fucoidan extracted from Cladosiphon okamuranus Tokida (Okinawa mozuku) was manufactured by South Product Co., Ltd. (Uruma, Japan). The characteristics of this fucoidan were as follows: average molecular weight of $49.8 \mathrm{kDa}$, L-fucose content of $52.7 \%$, uronic acid content of $18.0 \%$, and sulfate ion content of $17.6 \%$.

\subsection{Animals and Treatments}

Female BALB/c mice ( 8 weeks old) used in nonspecific study were purchased from BioLasco Taiwan Co. (Taipei, Taiwan). All animals were 8 weeks old at the start of the experiment and were housed in a normal environmentally controlled animal room $\left(22 \pm 3{ }^{\circ} \mathrm{C}, 12\right.$-h light/dark) with free access to pathogen-free feed and water. In this study, the mice were randomly divided into a negative control and four dose groups (102.5, 205, 410, and $1025 \mathrm{mg} / \mathrm{kg}$ body weight) with 10 mice in each group. Fucoidan was dissolved in distilled water and administered by oral gavage at $20 \mathrm{~mL} / \mathrm{kg}$ body weight daily for six weeks. The negative control $(0 \mathrm{mg} / \mathrm{kg}$ body weight) mice were treated identically with equal volumes of distilled water also via gavage throughout the study. All experiments were 
conducted according to the guidelines of the Institutional Animal Care and Use Committee of Medgaea Life Sciences.

\subsection{Preparation of Splenocytes Suspension, Peritoneal Macrophages, and Serum}

At the end of the animal experiments the mice were anesthetized and their blood was collected. The blood was centrifuged at $1200 \times g$ for $10 \mathrm{~min}$ to collect serum. The mice were injected with cold Hank's Balanced Salt Solution (HBSS; Sigma Aldrich, St. Louis, MO, USA) into the peritoneal cavity, and the peritoneal macrophage suspension at a density of $1 \times 10^{6} \mathrm{cell} / \mathrm{mL}$ was collected. The spleen was surgically removed and passed through nylon mesh $(75 \mu \mathrm{m})$. Splenocytes were washed with RPMI1640 medium (Gibco, Grand Island, NY, USA), and red blood cells were removed by HBSS and centrifuged at $300 \times g$ for $10 \mathrm{~min}$ to collect sediment after supernatant removal. RPMI 1640 medium was added and a cell suspension was prepared at a cell density of $2 \times 10^{8}$ cell $/ \mathrm{mL}$. The splenocytes suspension was used to measure proliferation and cytokine production.

\subsection{Immune Cell Proliferation}

Splenocytes were plated at a density of $4 \times 10^{5} \mathrm{cell} / \mathrm{mL}$ and stimulated with concanavalin A (Con A, Sigma Aldrich, St. Louis, MO, USA) and lipopolysaccharide (LPS, Sigma Aldrich, St. Louis, MO, USA). After incubation $\left(37^{\circ} \mathrm{C}, 5 \% \mathrm{CO}_{2}, 72 \mathrm{~h}\right)$, splenocytes were stained with a CellTiter $96^{\circledR} \mathrm{AQ}$ ueous One Solution Cell Proliferation Assay (Promega, Madison, WI, USA). After incubation $\left(37^{\circ} \mathrm{C}, 5 \% \mathrm{CO}_{2}\right.$, $4 \mathrm{~h}$ ), immune cell proliferation was determined by measuring the absorption at optical density (OD) of $490 \mathrm{~nm}$. Results were expressed as the stimulation index (S.I). The formula for calculating S.I is shown below:

$$
\text { S.I. }=\text { OD } 490 \mathrm{~nm} \text { of Con A and LPS-treated cells/OD } 490 \mathrm{~nm} \text { of untreated cells. }
$$

\subsection{Phagocytic Activity}

Peritoneal macrophages (density of $1 \times 10^{6} \mathrm{cell} / \mathrm{mL}$ ) and green fluorescent protein-labeled E. coli (Tunghai University, Taichung, Taiwan) were cultured $\left(37^{\circ} \mathrm{C}, 2 \mathrm{~h}\right)$ in RPMI1640 medium at E. coli/macrophage ratios of 25:1 and 50:1. The analytical buffer and trypan blue were added and analyzed by flow cytometry.

\subsection{Cytokine Production}

The splenocytes suspension (density of $4 \times 10^{5}$ cell $/ \mathrm{mL}$ ) was treated with Con A and LPS. After incubation $\left(37^{\circ} \mathrm{C}, 5 \% \mathrm{CO}_{2}, 72 \mathrm{~h}\right)$, cell-free supernatant was collected and cytokines, including IL-4, IL-5 and IFN- $\gamma$, were determined by enzyme-linked immunosorbent assay (ELISA) (eBioscience, San Diego, CA, USA). In addition, IL-2 were determined by ELISA at 24 and 48 hours after Con A and LPS stimulation.

\subsection{Determination of Serum Immunoglobulin}

Serum was collected for the detection of antibodies (IgM, IgG, IgA, and IgE) by ELISA (Bethyl Laboratories, Montgomery, TX, USA). The level of antibodies was calculated according to the following formula:

ELISA unit (E.U.) = (ODsample-ODblank $) /($ ODnegative Control-ODblank)

\subsection{Statistical Analysis}

Results were presented as the mean \pm standard deviation. Statistical analysis was performed by one-way ANOVA followed by Duncan's multiple range test using SPSS 22.0 software (IBM, USA). A value of $p<0.05$ was considered to be indicative of statistical significance. 


\section{Conclusions}

We evaluated the immunomodulatory effects of fucoidan derived from Cladosiphon okamuranus in mice. Fucoidan was shown to stimulate immune cell proliferation, phagocytes, and cell-mediated immunity. These results suggest that fucoidan regulates natural immunity.

Author Contributions: M.T. designed all of the experiments and the manuscript. W.-B.H., P.-Y.C., and Y.-C.L. performed the experiments and analyzed the data. T.N., T.M., and M.I. reviewed the manuscript.

Funding: This research received no external funding.

Acknowledgments: The authors would like to thank Calvin Hong (Medgaea Life Sciences) for his helpful advice on all experiments.

Conflicts of Interest: The authors declare no conflicts of interest.

\section{References}

1. Cumashi, A.; Ushakova, N.A.; Preobrazhenskaya, M.E.; D’Incecco, A.; Piccoli, A.; Totani, L.; Tinari, N.; Morozevich, G.E.; Berman, A.E.; Blilan, M.I.; et al. Consorzio Interuniversitario Nazionale per la Bio-Oncologia, Italy. A comparative study of the anti-inflammatory, anticoagulant, antiangiogenic, and antiadhesive activities of nine different fucoidans from brown seaweeds. Glycobiology 2007, 17, 541-552. [CrossRef] [PubMed]

2. Matsumoto, S.; Nagaoka, M.; Hara, T.; Kimura-Takagi, I.; Mitsuyama, K.; Ueyama, S. Fucoidan derived from Cladosiphon okamuranus Tokita ameliorates murine chronic colitis through the down-regulation of interleukin-6 production on colonic epithelial cells. Clin. Exp. Immunol. 2004, 136, 432-439. [CrossRef] [PubMed]

3. McClure, M.O.; Whitby, D.; Patience, N.; Gooderham, N.J.; Bradshaw, A.; Popov, R.C.; Weber, N.; Davies, D.S.; Cook, G.M.W.; Keynes, R.J.; et al. Dextrin sulfate and fucoidan are potent inhibitors of HIV infection in vitro. Antivir. Chem. Chemother. 1991, 2, 149-156. [CrossRef]

4. Atashrazm, F.; Lowenthal, R.M.; Woods, G.M.; Holloway, A.F.; Dickinson, J.L. Fucoidan and cancer: A multifunctional molecule with anti-tumor potential. Mar. Dugs 2015, 13, 2327-2346. [CrossRef] [PubMed]

5. Nagamine, T.; Hayakawa, K.; Kusakabe, T.; Takada, H.; Nakazato, K.; Hisanaga, E.; Iha, M. Inhibitory effect of fucoidan on Huh7 hepatoma cells through downregulation of CXCL12. Nutr. Cancer 2009, 61, 340-347. [CrossRef] [PubMed]

6. Ikeguchi, M.; Saito, H.; Miki, Y.; Kimura, T. Effect of fucoidan dietary supplement on the chemotherapy treatment of patients with unresectable advanced gastric cancer. Oncol. Lett. 2011, 2, 319-322. [CrossRef]

7. Azuma, K.; Ishihara, T.; Nakamoto, H.; Amaha, T.; Osaki, T.; Tsuka, T.; Imagawa, T.; Minami, S.; Takashima, O.; Ifuku, S.; et al. Effect of oral administration of fucoidan extracted from Cladosiphon okamuranus on tumor growth and survival time in a tumor-bearing mouse model. Mar. Drugs 2012, 10, 2337-2348. [CrossRef]

8. Ohnogi, H.; Naito, Y.; Higashimaru, Y.; Uno, K.; Yoshikawa, T. Immune efficacy and safety of fucoidan extracted from gagome kombu (Kjellmaniella crassifolia) in healthy japanese subjects. Jpn. J. Complement. Altern. Med. 2015, 12, 87-93. [CrossRef]

9. Murayama, H.; Tamauchi, H.; Hashimoto, M.; Nakano, T. Suppression of Th2 immune responses by mekabu fucoidan from Undaria pinnatifida sporophylls. Int. Arch. Allergy Immunol. 2005, 137, 289-294. [CrossRef]

10. Nishitsuji, K.; Arimoto, A.; Iwai, K.; Sudo, Y.; Hisata, K.; Fujie, M.; Arakaki, N.; Kushiro, T.; Konishi, T.; Shinzato, C.; et al. A draft genome of the brown alga, Cladosiphon okamuranus, S-strain: A platform for future studies of 'mozuku' biology. DNA Res. 2016, 23, 561-570. [CrossRef]

11. Nagaoka, M.; Shibata, H.; Kimura-Takagi, I.; Hashimoto, S.; Kimura, K.; Makino, T.; Aiyama, R.; Ueyama, S.; Yokokura, T. Structure study of fucoidan from Cladosiphon okamuranus Tokida. Glycoconj. J. 2009, 16, 19-26. [CrossRef]

12. Shibata, H.; Kimura-Takagi, I.; Nagaoka, M.; Hashimoto, S.; Sawada, H.; Ueyama, S.; Yokokura, T. Inhibitor effect of Cladosiphon fucoidan on the adhesion of Helicobacter pylori to human gastric cells. J. Nutr. Sci. Vitaminol. 1999, 45, 325-336. [CrossRef] 
13. Shibata, H.; Iimuro, M.; Uchiya, N.; Kawamori, T.; Nagaoka, M.; Ueyama, S.; Hashimoto, S.; Yokokura, T.; Sugimura, T.; Wakabayashi, K. Prevent effects of Cladosiphon fucoidan against Helicobacter pylori infect in Mongolian gerbils. Helicobacter 2003, 8, 59-65. [CrossRef]

14. Nagaoka, M.; Shibata, H.; Kimura-Takagi, I.; Hashimoto, S.; Aiyama, R.; Ueyama, S.; Yokokura, T. Anti-ulcer effects and biological activities of polysaccharides from marine algae. Biofactors 2000, 12, 267-274. [CrossRef]

15. Yamamoto, Y.; Suzuki, T.; Hirano, M.; Nagaoka, M.; Hashimoto, S.; Shibata, H.; Kimura-Takagi, I.; Ueyama, S.; Kudo, T.; Yoshikawa, M.; et al. Effect of fucoidan and fucoidan containing tea on gastric ulcer and non-ulcer dyspepsia. Jpn. Pharmacol. Ther. 2000, 28, 63-70. (In Japanese)

16. Chen, Y.M.; Tsai, Y.H.; Tsai, T.Y.; Chiu, Y.S.; Wei, L.; Chen, W.C.; Huang, C.C. Fucoidan supplementation improves exercise performance and exhibits anti-fatigue action in mice. Nutrients 2015, 7, 239-252. [CrossRef]

17. Abe, S.; Hiramatsu, K.; Ichikawa, O.; Ikeda, T.; Kawamoto, H.; Kasagi, T.; Miki, Y. Effects of mozuku fucoidan on defecation and fecal condition in human. J. Yonago Med. Assoc. 2010, 61, 122-128. (In Japanese)

18. Tomori, M.; Matsuda, K.; Nakamura, Y.; Kadena, K.; Shimoji, S.; Nagamine, T.; Iha, M. Effect of Cladosiphon okamuranus fucoidan containing drink on improvement of defecation in healthy subjects with mild constipation. Jpn. Pharmacol. Ther. 2016, 44, 1621-1626. (In Japanese)

19. Haneji, K.; Matsuda, T.; Tomita, M.; Kawakami, H.; Ohshiro, K.; Uchihara, J.N.; Masuda, M.; Takasu, N.; Tanaka, Y.; Ohta, T.; et al. Fucoidan extracted from cladosiphon okamuranus Tokida induces apoptosis of human T-cell leukemia virus type 1 -infected T-cell lines and primary adult T-cell leukemia cells. Nutr. Cancer 2005, 52, 189-201. [CrossRef]

20. Araya, N.; Takahashi, K.; Sato, T.; Nakamura, T.; Sawa, C.; Hasegawa, D.; Ando, H.; Aratani, S.; Yagishita, N.; Fujii, R.; et al. Fucoidan therapy decreases the proviral load in patients with human T-lymphotropic virus type-I-associated neurological disease. Antivir. Ther. 2011, 16, 89-98. [CrossRef]

21. Irhimeh, M.R.; Fitton, J.H.; Lowenthal, R.M.; Kongtawelert, P. A quantitative method to detec fucoidan in human plasma using a novel antibody. Methods Find. Exp. Clin. Pharmacol. 2005, 27, 705-710. [CrossRef]

22. Tokita, Y.; Nakajima, K.; Mochida, H.; Iha, M.; Nagamine, T. Development of fucoidan-specific antibody and measurement of fucoidan in serum and urine by sandwich ELISA. Biosci. Biotechnol. Biochem. 2010, 74, 350-357. [CrossRef]

23. Murayama, H.; Tamauchi, H.; Iizuka, M.; Nakano, T. The role of NK cells in antitumor activity of dietary fucoidan from Undaria pinnatifida Sporophylls (Mekabu). Planta Med. 2006, 72, 1415-1417. [CrossRef]

24. Li, B.; Lu, F.; Wei, X.; Zhao, R. Fucoidan: Structure and bioactivity. Molecules 2008, 13, 1671-1695. [CrossRef]

25. Nagamine, T.; Nakazato, K.; Tomioka, S.; Iha, M.; Nakajima, K. Intestinal absorption of fucoidan extracted from the brown seaweed, Cladosiphon okamuranus. Mar. Drugs 2015, 13, 48-64. [CrossRef]

26. Tokita, Y.; Hirayama, M.; Nakajima, K.; Tamaki, K.; Iha, M.; Nagamine, T. Detection of fucoidan in urine after oral intake of traditional japanese seaweed, Okinawa mozuku (Cladosiphon okamuranus Tokida). J. Nutr. Sci. Vitaminol. 2017, 63, 419-421. [CrossRef]

27. Kadena, K.; Tomori, M.; Iha, M.; Nagamine, T. Absorption study of mozuku fucoidan in japanese volunteers. Mar. Drugs 2018, 16, 254. [CrossRef]

28. Shimizu, J.; Wada-Funada, U.; Mano, H.; Matahira, Y.; Kawaguchi, M.; Wada, M. Proportion of murine cytotoxic $\mathrm{T}$ cells is increased by high molecular-weight fucoidan extracted from okinawa mozuku (Cladosipohn okamuranus). J. Health Sci. 2005, 51, 394-397. [CrossRef]

29. Jang, J.Y.; Moon, S.Y.; Joo, H.G. Differential effects of fucoidans with low and high molecular weight on the viability and function of spleen cells. Food Chem. Toxicol. 2014, 68, 234-238. [CrossRef]

30. Doi, T.; Higashino, K.; Kurihara, Y.; Wada, Y.; Miyazaki, T.; Nakamura, H.; Uesugi, S.; Imanishi, T.; Kawabe, Y.; Itakura, H.; et al. Charge collagen structure mediate recognition of negatively charged macromolecules by macrophage scavenger receptors. J. Biol. Chem. 1993, 268, 2126-2133.

31. Takai, M.; Miyazaki, Y.; Tachibana, H.; Yamada, K. The enhancing effect of fucoidan derived from Undaria pinnatifida on immunoglobulin production by mouse spleen lymphocytes. Biosci. Biotechnol. Biochem. 2014, 78, 1743-1747. [CrossRef]

(C) 2019 by the authors. Licensee MDPI, Basel, Switzerland. This article is an open access article distributed under the terms and conditions of the Creative Commons Attribution (CC BY) license (http://creativecommons.org/licenses/by/4.0/). 